\title{
PARTISIPASI MASYARAKAT DALAM PENYELENGGARAAN FESTIVAL PALANG PINTU SEBAGAI ATRAKSI WISATA BUDAYA DI KAWASAN KEMANG JAKARTA SELATAN
}

\author{
Indri Dwi Hartono, Riza Firmansyah \\ Fakultas Pariwisata -Universitas Pancasila \\ E-mail: tourism@univpancasila.ac.id
}

\begin{abstract}
Palang Pintu Festival is an annual program organized by Forkabi (Betawi Children's Communication Forum) DPRT Bangka Kemang and Betawi Cultural Center namely Padepokan Manggar Kelape featuring Betawi culture and performing arts and community participation. The purpose of the festival is to preserve and introduce Betawi culture in Kemang area. This study discusses the elements of cultural tourism and the form of community participation in the Palang Pintu Festival. Data collection methods used were observations, surveys using questionnaires, interviews, and documentation then analyzed and presented in quanititative manner and supported by qualitative data, where the results will be presented in the percentage number. Technique of data analysis used in this research is with validity test, reliability test and also use rank spearman analysis method. The result of this research shows that the characteristic of society is seen from the age type dominated by the age of 15-25 years as much as $39 \%$ and the sexes, both men and women are the same size because this research uses roscoe theory in determining the number of respondents, if the sample is divided into 2 then Per sub sample to 30 respondents respectively. The level of community participation in the Palang Pintu Festival is at a moderate level, this is because the community participating in the Kemang area is more interested if the activities are rewarded. For a community characteristic relationship with participation does not have a strong relationship or it can be said has nothing to do in participation with the characteristics of society in any category. Because of all the people who participated in the Palang Pintu Festival plays an important role in preserving and introducing Betawi Culture to the wider community.
\end{abstract}

Keywords: Kemang Palang Pintu Festival, Community Participation, Cultural Tourism.

\section{PENDAHULUAN}

Pariwisata berbasis masyarakat merupakan peluang untuk menggerakkan segenap potensi dan dinamika masyarakat, guna mengimbangi peran pelaku usaha pariwisata skala besar. Menurut Pitana (1999) dalam Anita (2016), menyebutkan bahwa pembangunan dalam sektor pariwisata serta pendayagunaan sumber potensi kepariwisataan menjadi kegiatan ekonomi yang dapat diandalkan untuk memperbesar penerimaan devisa, memperluas dan meratakan kesempatan berusaha dari lapangan kerja terutama bagi masyarakat setempat, mendorong pembangunan daerah serta memperkenalkan alam, nilai dan budaya bangsa.

Pada umumnya sejumlah kalangan sepakat perlu dikembangkangkan partisipasi sebagai upaya menyertakan 
$\begin{array}{lcr}\begin{array}{l}\text { masyarakat } \\ \text { mendorong, }\end{array} & \begin{array}{r}\text { seluas-luasnya } \\ \text { berkembangnya }\end{array} & \begin{array}{r}\text { yang } \\ \text { proses }\end{array} \\ \text { kebersamaan } & \text { (Sastrayuda, } & 2010) .\end{array}$ Keterlibatan/partisipasi masyarakat menurut Adi (2007) adalah keikutsertaan masyarakat dalam proses pengidentifikasian masalah dan memanfaatkan potensi yang ada di masyarakat, pemilihan dan pengambilan keputusan tentang alternatif solusi untuk menangani masalah, pelaksanaan upaya mengatasi masalah, dan keterlibatan masyarakat dalam proses mengevaluasi perubahan yang terjadi. Masyarakat ikut serta dan berperan aktif dengan stakeholder untuk menjamin keberhasilan pembangunan. Partisipasi disini bisa berupa partisipasi yang dijelaskan dalam 7 (tujuh) tipologi partisipasi menurut Pretty (1995), yaitu Partisipasi Manipulasi, Partisipasi Pasif, Partisipasi Konsultasi, Partisipasi Insentif, Partisipasi Fungsional, Partisipasi Interaktif, Kemandirian.

Dalam dunia pariwisata, budaya dan adat istiadat yang masih hidup dan berkembang ditengah masyarakat telah menjadikan daya tarik tersendiri bagi wisatawan untuk berkunjung ke suatu daerah. Kebudayaan dan tradisi yang berkembang di masyarakat merupakan aset wisata budaya yang memiliki nilai dan keunggulan tersendiri dan sebagai mata rantai warisan serta kekayaan budaya bangsa Indonesia. Potensi budaya adat dan istiadat yang dimiliki hendaknya dijaga dan dilestarikan. Menurut Koentjaraningrat (2009) dalam Prasetyo (2015), pariwisata budaya yaitu diartikan sebagai kebudayaan untuk menyatakan hasil karya manusia yang indah-indah. Pariwisata budaya merupakan jenis pariwisata yang berdasarkan pada mosaik tempat, tradisi, kesenian, upacara-upacara, dan pengalaman yang memotret bangsa atau suku bangsa, yang mereflesikan keanekaragaman dan identitas dari masyarakat atau bangsa. Menurut Hardjowigeno et al. (1994) dalam
Kodariyah (2005) wisata budaya adalah kegiatan pariwisata dimana kekayaan budaya setempat menjadi objek wisatanya. Unsur-unsur yang menyusun suatu kegiatan wisata budaya terdiri dari 3 (tiga) kategori, yaitu Seni Budaya, Seni Bangunan, dan Pagelaran Budaya. Dari pengertian-pengertian tersebut dapat disimpulkan bahwa salah satu pariwisata budaya yang dapat dijadikan sebagai atraksi wisata budaya di suatu daerah yang akan mendatangkan wisatawan mancanegara maupun wisatawan lokal yaitu pertunjukan budaya atau festival budaya yang berupa tradisi, kesenian, adat-istiadat serta didukung dengan keberadaan arsitektur bangunan atau suatu kawasan yang mencerminkan nilai-nilai kebudayaan sebagai identitas dari daerah tersebut.

Di Jakarta Selatan tepatnya Kawasan Kemang terdapat festival budaya betawi yang hingga kini masih dilestarikan oleh masyarakat lokal maupun pemerintah dan bisa juga dijadikan sebagai potensi atraksi wisata budaya yang akan mendatangkan wisatawan ke Kota Jakarta.

Kemang berada di Kelurahan Bangka, Kecamatan Mampang Prapatan, Jakarta Selatan. Awal tahun 1950-an, kawasan Kemang merupakan tanah perkebunan. Disini banyak dijumpai pohon Kemang (Mangifera Kemangcaecea) sehingga kemudian kawasan ini dikenal dengan sebutan itu, namun saat ini pohon kemang sudah jarang dijumpai. Selain mengolah kebun, orang-orang Betawi juga ada yang bekerja sebagai peternak dan sebagian lainnya memproduksi tahu. Tahun 1960an, mulai berkembang permukiman yang ditinggali oleh penduduk Betawi dan juga terdapat rumah-rumah khas Betawi yang masih memadati Kampung Kemang, biasa disebut "Rumah Kebaya". Sejak dibukanya jembatan Kemang-Prapanca, rumah model Betawi berangsur langka (www.jakarta.go.id). Ada beberapa penyelenggaraan festival yang digagas 
oleh masyarakat sekitar Kemang dan kemudian pemerintah ikut serta mengembangkan kegiatan acara yang sudah diadakan secara rutin tiap tahunnya. Salah satu penyelenggaraan festival di Kota Jakarta yaitu Festival Palang Pintu yang di adakan di kawasan Kemang, Jakarta Selatan.

Festival Palang Pintu merupakan agenda rutin tahunan yang telah digelar sejak tahun 2006 oleh Forkabi (Forum Komunikasi Anak Betawi) DPRt Bangka Kemang dan pusat kebudayaan Betawi yaitu Padepokan Manggar Kelape. Selain untuk memeriahkan dan memelihara suasana Budaya Betawi di kawasan Kemang juga sekaligus menjadi pembuka perayaan ulang tahun Ibukota Jakarta setiap tahunnya. Seni budaya dalam festival ini akan dikemas dalam berbagai acara seperti bazaar, permainan, fun bike, aneka lomba, arak-arakan, kuliner, dan juga karnaval budaya.

Dan Festival Palang Pintu adalah salah satu pagelaran seni budaya betawi di kawasan Kemang yang harus dilestarikan, karena perlahan-lahan wajah kawasan Kemang ini berubah menjadi lebih modern, banyak berdiri bangunanbangunan megah seperti mall, dan apartemen. Banyaknya pertokoan, restoran, kafe atau tempat hiburan lainnya menjadi pertanda kawasan ini menjadi salah satu pusat perekonomian modern. Karena perkembangan yang sangat pesat dan untuk tetap menjaga kelestarian Budaya Betawi di kawasan Kemang ini, maka salah satu bentuk kepedulian yang bisa dilakukan yaitu dengan mengembalikan Budaya Betawi dalam bentuk kesenian yang berkaitan dengan Budaya Betawi.

\section{METODE PENELITIAN}

Peneliti mengambil lokasi di acara Festival Palang Pintu yang ke-12 dan sekitar Jalan Kemang Raya, Kelurahan Bangka, Kecamatan Mampang Prapatan, Jakarta Selatan. Sebagai bahan
Oleh karena itu, penelitian ini akan difokuskan pada partisipasi masyarakat dalam penyelenggaraan Festival Palang Pintu untuk dijadikan sebagai salah satu atraksi wisata budaya di Kota Jakarta, sehingga peneliti dapat melihat Festival Palang Pintu berdasarkan teori Hardjowigeno et al. (1994) tentang Unsur-Unsur Wisata Budaya untuk dijadikan sebagai atraksi wisata budaya di Kota Jakarta. Dan untuk mengetahui tingkat partisipasi masyarakat berdasarkan teori Pretty (1995) tentang Tipologi Partisipasi Masyarakat dalam penyelenggaraan Festival Palang Pintu yang sudah diadakan 12 kali dan bagaimana hubungan partisipasi masyarakat dalam Festival Palang Pintu dengan karakteristik responden (masyarakat).

\section{Tujuan Penelitian}

1. Untuk mengidentifikasi Festival Palang Pintu Kemang sebagai atraksi wisata budaya di kawasan Kemang Jakarta Selatan.

2. Untuk mengidentifikasi partisipasi masyarakat dalam penyelenggaraan Festival Palang Pintu sebagai atraksi wisata budaya di kawasan Kemang, Jakarta Selatan.

3. Untuk mengidentifikasi hubungan partisipasi dengan karakteristik masyarakat.

pertimbangan untuk menjadikan penyelenggaraan Festival Palang Pintu sebagai salah satu atraksi wisata budaya di Kota Jakarta dan keikutsertaan atau partisipasi masyarakat di sekitar kawasan Kemang atas penyelenggaraan Festival 
Palang Pintu untuk tetap melestarikan Budaya Betawi. Penelitian ini dilaksanakan selama 3 bulan, dimulai pada bulan Maret hingga bulan Juli 2017.

Penelitian ini menggunakan penelitian campuran (mixed methods). Penelitian campuran adalah penelitian yang menggabungkan pendekatan kuantitatif dan kualitatif dengan tujuan untuk mendapatkan pemahaman yang lebih tentang suatu permasalahan penelitian atau isu dibandingkan satu pendekatan saja (Creswell, 2010).

Dari pengertian diatas dapat disimpulkan bahwa dalam penelitian ini menggunakan mix methods. Pada tahap pertama yaitu menggunakan metode kualitatif yang menggambarkan/mendeskripsikan tentang penyelenggaraan dan partisipasi masyarakat dalam Festival Palang Pintu dengan menggunakan variabel-variabel menurut teori Hardjowigeno et al. (1994) yaitu tentang unsur-unsur wisata budaya dan teori lainnya yang digunakan yaitu menurut Pretty (1995) tentang tipologi partisipasi masyarakat. Dan kemudian dari variabel-variabel tersebut dijadikan sebagai keyword (kata kunci) yang dibuat menjadi kalimat-kalimat pernyataan sebagai indikator di dalam kuesioner dan panduan wawancara yang digunakan.

Pada tahap kedua yaitu menggunakan metode kuantitatif, metode ini digunakan untuk melihat seberapa besar tingkat partisipasi masyarakat dalam Festival Palang Pintu dengan menggunakan metode analisis data yang akan digunakan. Data tersebut didapat dari hasil kuesioner sehingga dapat dikelompokkan ke dalam tipologi partisipasi masyarakat kemudian partisipasi masyarakat dihubungkan dengan karakteristik responden dengan partisipasi masyarakat.

Jenis data yang digunakan adalah data primer dan sekunder. Data primer diperoleh dari pengamatan langsung dilapangan, sedangkan data sekunder diperoleh dari data yang telah dipublikasikan sebelumnya. Untuk mendapatkan data tersebut dibutuhkan adanya informan dan sumber informasi.

1. Data Primer adalah data yang diperoleh langsung dari informan dan responden, dengan menyebarkan kuesioner kepada pengunjung yang pernah datang atau yang mengetahui Festival Palang Pintu serta wawancara secara langsung dengan Ketua Forkabi DPRt Bangka Kemang dan Ketua Padepokan Manggar Kelape. Dari hasil kuesioner dan wawancara yang diperoleh masih perlu diolah lebih lanjut untuk mendapatkan kesimpulan dari penelitian tersebut. Data tersebut berupa tingkat partisipasi masyarakat dan data yang berkaitan dengan unsurunsur wisata budaya dalam Festival Palang Pintu untuk dijadikan sebagai salah satu atraksi wisata budaya.

2. Data Sekunder adalah data yang diperoleh secara tidak langsung melalui buku-buku perpustakaan, dokumentasi, artikel, tulisan ilmiah, penelitian sebelumnya dan keterangan yang lain yang berhubungan dengan penelitian. Contohnya seperti teori-teori menurut para ahli dan data-data yang berkaitan dengan penelitian.

Dalam menentukan jumlah sampel yang akan digunakan, maka peneliti menggunakan teori menurut Roscoe, Sugiyono (2009) dalam Lestari (2014) memberikan rule of thumbs mengenai sample size, yaitu apabila sample size lebih dari 30 dan kurang dari 500 adalah tepat untuk semua riset dan jika sampel terbagi dalam beberapa sub sampel maka jumlah sampel minimum untuk tiap sub sampel adalah 30 . 
Karena populasi dalam penelitian ini besar, maka peneliti dapat mengambil sebagian sampel untuk diteliti yang tentunya mewakili populasi tersebut. Sampel dari penelitian ini adalah sebagian masyarakat disekitar Kemang, yaitu 30 orang untuk berjenis kelamin perempuan dan 30 orang untuk berjenis kelamin lakilaki. Dan juga sampel yang diambil berasal dari pengunjung yang pernah datang atau mengetahui tentang Festival Palang Pintu yang berjumlah 30 orang baik perempuan dan laki-laki.

Sementara itu, pemilihan terhadap informan dilakukan secara sengaja (purposive sampling) dan jumlahnya tidak ditentukan, informan tersebut adalah Ketua Forkabi DPRt Bangka Kemang yaitu Bapak Mustofa dan Ketua Padepokan Manggar Kelape yaitu Bapak Edy Mulyadi.

Analisis data yang dilakukan meliputi Analisis Statistik Deskriptif, Transformasi Data Ordinal Menjadi Data Interval menggunakan Metode Suksesif Interval untuk transformasi dari data ordinal ke data interval sebelum dilakukannya skoring, Deskriptif Kualitatif, dan Rank Correlation Spearman. Data tersebut diolah menggunakan aplikasi Microsoft Excel 2007 dan SPSS (Statistical Program for Social Sciences).

Sugiyono (2012) Uji validitas adalah suatu langkah pengujian yang dilakukan terhadap isi (content) dari suatui nstrumen, dengan tujuan untuk mengukur ketepatan instrumen yang digunakan dalam suatu penelitian. Dasar pengambilan keputusan uji validitas adalah sebagai berikut:

1. Jika p-value < alpha 0,05 maka item pernyataan valid.

2. Jika p-value > alpha 0,05 maka item pernyataan tidak valid.

Sugiyono (2012) Uji reliabilitas merupakan suatu pengujian terhadap

\begin{tabular}{|c|c|c|c|c|}
\hline No & Variable & Indikator & $\begin{array}{l}\mathrm{Sig} / \mathrm{p} \\
\text { Value }\end{array}$ & Keterangan \\
\hline \multirow[t]{3}{*}{1.} & Manipulasi & X. 11 & .000 & Valid \\
\hline & & X. 12 & .000 & Valid \\
\hline & & X.13 & .000 & Valid \\
\hline \multirow[t]{2}{*}{2.} & Pasif & X. 21 & .000 & Valid \\
\hline & & X. 22 & .000 & Valid \\
\hline \multirow[t]{2}{*}{3.} & Konsultasi & X. 31 & .000 & Valid \\
\hline & & X. 32 & .008 & Valid \\
\hline \multirow[t]{2}{*}{4.} & Insentif & X. 41 & .000 & Valid \\
\hline & & X. 42 & .000 & Valid \\
\hline \multirow[t]{2}{*}{5.} & Fungsional & X. 51 & .000 & Valid \\
\hline & & X. 52 & . 000 & Valid \\
\hline \multirow[t]{2}{*}{6.} & Interaktif & X. 6.1 & .000 & Valid \\
\hline & & X. 6.2 & .000 & Valid \\
\hline \multirow[t]{2}{*}{7.} & Kemandirian & X. 71 & .000 & Valid \\
\hline & & X.72 & .000 & Valid \\
\hline
\end{tabular}

konsistensi, akurasi prediktabilitas alat ukur. Reliabilitas adalah istilah yang dipakai untuk menunjukan sejauh mana hasil pengukuran relatif konsisten apabila pengukuran diulang dua kali atau lebih. Suatu instrument dapat dianggap reliable jika memiliki koofisiensi (a) sebesar 0,6 atau lebih.

1. Jika koefisien alpha (a) pengujian lebih besar dari > 0,6 maka pernyataan dalam kuesioner layak digunakan (reliabel).

2. Jika koefisien alpha (a) pengujian kurang dari $<0,6$ maka pernyataan dalam kuesioner tidak layak digunakan (tidak reliabel). 


\section{HASIL dan PEMBAHASAN}

Tradisi Palang Pintu merupakan salah satu tradisi yang menjadi identitas masyarakat Betawi di Jakarta. Tradisi ini

\begin{tabular}{|c|c|c|c|}
\hline No & Variable & $\begin{array}{c}\text { Koofisien } \\
\text { Korelasi }\end{array}$ & Keterangan \\
\hline 1. & Manipulasi & .628 & Reliabel \\
\hline 2. & Pasif & .784 & Reliabel \\
\hline 3. & Konsultasi & .827 & Reliabel \\
\hline 4. & Insentif & .644 & Reliabel \\
\hline 5. & Fungsional & .822 & Reliabel \\
\hline 6. & Interaktif & .651 & Reliabel \\
\hline 7. & Kemandirian & .897 & Reliabel \\
\hline
\end{tabular}

menjadi bagian dalam prosesi upacara pernikahan adat Betawi sejak zaman nenek moyang. Perpaduan silat dan seni pantun yang jenaka menjadi hal yang dominan dalam tradisi Palang Pintu. Hal inilah yang kemudian menjadi landasan digelarnya festival tahunan bernama Festival Palang Pintu yang bertempat di Kawasan Kemang, Jakarta.

Forkabi (Forum Komunikasi Anak Betawi) dan Padepokan Manggar Kelape, pusat kebudayaan Betawi di kawasan Kemang yang merintis digelarnya Festival Palang Pintu. Festival ini bertujuan untuk mengembalikan Budaya Betawi di Kawasan Kemang. Meski pada awalnya sulit berkembang di tengah budaya barat, namun secara perlahan misi mereka diterima di tengah masyarakat, khususnya warga negara asing di Kawasan Kemang. Sejak tahun 2006, Festival Palang Pintu diadakan untuk memeriahkan suasana Betawi di kawasan Kemang.

Dalam festival ini, kontes tradisi palang pintu menjadi bagian penting yang dilombakan. Lomba ini memiliki tujuan untuk melestarikan dan memperkenalkan budaya Betawi ke masyarakat yang hadir dari segala penjuru di festival ini.
Selain itu, Festival Palang Pintu juga memiliki tujuan mensosialisasikan seni budaya tradisional Betawi dan menjadi media untuk mempertahankan dan melestarikan budaya Betawi. Festival ini juga menjadi ajang untuk menjalin silaturahmi dari para pegiat seni dan tokoh budaya Betawi. Selain menjadi ajang memperkenalkan budaya, festival ini juga tidak ketinggalan menampilkan segala sesuatu yang berhubungan dengan masyarakat Betawi. Kehadiran berbagai macam bazar dan pasar kuliner menjadikan festival ini semakin semarak.

Meski identik dengan Betawi, ada beberapa budaya daerah lain yang juga ikut serta memeriahkan seperti daerah Papua. Dengan menampilkan duta Papua bertujuan agar orang tahu bukan hanya kebudayaan Betawi saja di Festival Palang Pintu. Kebudayaan Papua ditampilkan dengan menampilkan Duta Papua dengan menggunakan pakaian Budaya Papua. Yang dihadirkan asli Duta Papua, bernama Michel dan Wina, merupakan perwakilan Papua di Jakarta. Selain dari daerah Papua, ada juga dari kesenian dari daerah Ponorogo yaitu Reog Ponorogo (www.merdeka.com)

Selain dukungan dari masyarakat sekitar kawasan Kemang di Festival Palang Pintu, acara ini juga didukung penuh dari pemerintah, mulai dari piala Gubernur dalam perlombaan Palang Pintu yang diperebutkan oleh peserta dari berbagai pedepokan-padepokan budaya betawi se-Jabodetabek. Kementrian Pemuda dan Olahraga juga memberikan piala untuk perlombaan tari, band, mewarnai dan menggambar. Dukungan dari Kementrian Pendidikan dan Budaya serta Dinas Pariwisata Budaya Jakarta Selatan, juga didukung oleh Badan Narkotika Nasional dan peran dari BNN itu sendiri yaitu sebagai wadah pengetahuan tentang jenis-jenis narkoba dan sejenisnya. Memberikan informasi bagaimana cara merehabilitas pengguna 
narkoba, serta secara langsung mengajak masyarakat untuk memerangi narkoba. Dan acara tersebut didukung oleh Kepolisian Mampang Prapatan untuk pengamanan dan pengaturan lalu lintas selama Festival Palang Pintu berlangsung.

\section{Festival Palang Pintu Kemang Sebagai Atraksi Wisata Budaya}

Menururt Hardjowigeno et al. (1994) dalam Kodariyah (2005), wisata budaya adalah kegiatan pariwisata dimana kekayaan budaya setempat menjadi objek wisatanya. Unsur-unsur yang menyusun suatu kegiatan wisata budaya terdiri dari 3 kategori, yaitu Seni Budaya, Seni Bangunan dan Pagelaran Budaya.

Dan berikut adalah data-data yang didapat melalui obesrvasi langsung ke lapangan dengan melihat teori dari Hardjowigeno et al. (1994).

1. Seni Budaya

Seni budaya mencakup kerajinan tangan yang menggambarkan kebudayaan Betawi berupa boneka Ondel-Ondel, sandal khas orang Betawi, gantungan kunci yang menyerupai Rebana Ketimpring, dan kerajinan tangan lainnya yaitu Kembang Kelape atau orang Betawi biasa menyebutnya Manggar Kelape, yang merupakan benda yang bentuknya menyerupai kembang kelapa. Dan menurut hasil observasi di lapangan dari berbagai pengunjung yang pernah datang atau mengetahui tentang Festival Palang Pintu, mereka mengatakan bahwa terdapat kerajinan tangan yang menggambarkan kebudayaan asli Betawi dan mereka tertarik untuk membelinya. Dengan adanya acara seperti ini masyarakat menjadikan wadah untuk mengetahui apa saja kerajinan tangan menggambarkan masyarakat Betawi asli. Dimana selain dengan adanya acara ini kerajinankerajinan tangan asli Betawi hanya didapatkan di tempat-tempat tertentu.
Tata cara adat yang mencerminkan Budaya Betawi, seperti Tradisi Buka Palang Pintu adalah salah satu tata cara adat asal Betawi, dimana di dalam tradisi tersebut terdapat ragam seni Betawi yang menjadi syarat dalam tradisi itu sendiri, mulai dari Pantun, Pencak Silat, Sike, Rebana Ketimpring, Ondel-Ondel, Kembang Kelape dan Musik Marawis. Di Festival Palang Pintu terdapat tradisi pernikahan Budaya Betawi, meskipun tradisi tersebut hanya sekedar untuk menghibur pengunjung yang datang. Tetapi di acara ini tradisi tersebut dilakukan selayaknya seperti tradisi pernikahan Budaya Betawi sungguhan. Dan dalam acara Buka Palang Pintu tidak hanya dilakukan pada saat tradisi pernikahan saja tetapi pada saat penyambutan hadirnya Wakil Wali Kota Jakarta Selatan ketika ingin menuju ke panggung utama. Berikut ragam seni dalam tata cara adat pernikahan Budaya Betawi yang ada di Festival Palang Pintu:

\section{Pantun}

Pantun menjadi pengantar dialog yang digunakan untuk menghidupkan dan mencairkan suasana. Dengan adanya pantun sebagai pengantar dialog, maka tradisi Buka Palang Pintu juga untuk bersilaturahmi dari kedua belah pihak dengan menggunakan pantun sebagai pengantar berkomunikasi. Dalam hal ini dilakukan oleh para peserta Festival Palang Pintu.

$>$ Pencak Silat

Dalam Festival Palang Pintu, Pencak Silat dilakukan oleh salah satu anggota yang menjadi perwakilan dari para peserta Palang Pintu tersebut. Pencak Silat menjadi syarat pertama yang diajukan pengantin perempuan kepada pengantin laki-laki. Pencak silat dalam tradisi Buka Palang Pintu melambangkan keperkasaan yang berarti bahwa laki-laki Betawi harus kuat, gagah dan secara lahir batin siap melindungi istri, anak dan 
keluarganya. Dan dalam Festival Palang Pintu, Pencak Silat juga dilakukan oleh anak-anak binaan dari Padepokan Manggar Kelape yang berusia dari 7 tahun hingga 15 tahun. Pencak Silat ini dilakukan untuk pembukaan Festival Palang Pintu dan diiringi oleh musik dari Gambang Kromong.

Sike

Dalam tradisi Buka Palang Pintu, lantunan sike yang dibacakan menjadi symbol seorang laki-laki muslim yang taat pada ajaran Islam. Sike dalam Festival Palang Pintu dilantunkan oleh salah satu peserta yaitu seorang tukang sike yang berperan sebagai wakil dari pengantin laki-laki. Sike dibaca dengan cara dilagukan, seperti ayat-ayat yang dibacakan qori' dalam Musabaqah Tilawatil Quran (MTQ).

Rebana Ketimpring

Dalam Festival Palang Pintu, Rebana Ketimpring digunakan oleh peserta Palang Pintu untuk mengarak pengantin laki-laki yang sedang menuju ke panggung utama dimana pengantin perempuan sudah menunggu di atas panggung. Dalam iring-iringan tersebut, pemain rebana ngarak berada di depan pengantin laki-laki beserta para anggota peserta tersebut selayaknya seperti sanak keluarganya. Hal ini sebagai tanda bahwa ada rombongan pengantin laki-laki yang sedang menuju ke panggung utama untuk menemui pengantin perempuan.

Menurut hasil dari observasi yang didapat di lapangan, pengunjung mengatakan bahwa Festival Palang Pintu sepenuhnya mencerminkan salah satu tata cara adat Budaya Betawi, mulai dari awal hingga akhir, meskipun hanya untuk ajang perlombaan atau untuk menghibur pengunjung yang datang tetapi pengunjung dapat merasakan suasana dari tradisi pernikahan Budaya Betawi seperti aslinya. Dengan adanya tradisi buka Palang Pintu ini, pengunjung yang datang dengan membawa keluarga dapat dijadikan pengetahuan bagi anak-anak sejak dini tentang tata cara adat tradisi Kebudayaan Betawi.

Pesta rakyat yang berhubungan dengan acara Budaya Betawi Pesta rakyat yang terdapat di Festival Palang Pintu antara lain yaitu pawai atau yang biasa disebut karnaval dari berbagai daerah seperti ondel-ondel, reog ponorogo, barongsai dan kostum asal daerah Papua. Selain itu adanya Fun Bike yang diadakan pada pagi hari, masyarakat antusias untuk mengikuti acara ini dengan menghias sepeda mereka masing-masing semenarik mungkin dan diikuti mulai dari anak kecil hingga dewasa. Kemudian pameran pakaian daur ulang, fashion show dari pameran ini dilaksanakan di lokasi Festival Palang Pintu yaitu di sepanjang jalan Kemang Raya, dan masih banyak lagi pesta rakyat yang turut memeriahkan acara tersebut. Menurut hasil observasi yang didapat di lapangan dari berbagai pengunjung yang pernah datang dan mengetahui tentang Festival Palang Pintu, pesta rakyat yang diadakan tidak sepenuhnya berasal dari Kebudayaan Betawi, contohnya seperti adanya karnaval dari Reog Ponorogo dan Papua. Dengan adanya Budaya dari daerah lain yang mengikuti acara Budaya Betawi membuat para pengunjung mengetahui kesenian yang berasal dari daerah lain, terutama untuk anak-anak. Kemudian dengan diadakannya Fun Bike yang diikuti dari kalangan muda hingga dewasa para pengunjung mengatakan dapat melebur bersama masyarakat asli Betawi maupun masyarakat umum. Dan untuk pameran pakaian daur ulang, pengunjung mengaku sangat tertarik untuk menyaksikannya. Dengan adanya pameran tersebut pengunjung mendapatkan inspirasi untuk menggunakan barang-barang bekas atau yang sudah tidak terpakai dan dijadikan sesuatu yang bermanfaat. 
Adanya produk lokal di Festival Palang Pintu, berbagai macam produk dijajakan sepanjang jalan di lokasi Festival Palang Pintu, mulai dari produk-produk lokal khas Betawi seperti kerajinan tangan, pakaian adat Betawi untuk laki-laki dan perempuan dari usia muda hingga dewasa, serta makanan dan minuman khas betawi. Tidak hanya produk lokal asal Betawi, tetapi banyak produk-produk di luar dari Kebudayaan Betawi, seperti adanya standstand yang menjual pakaian dengan berbagai model, alat-alat kebutuhan rumah tangga, peralatan sekolah, berbagai macam kuliner, selain itu terdapat pula stand dari Perusahaan Listrik Negara, stand yang menawarkan mobil dan lain-lain. Dari hasil observasi yang ada di lapangan pendapat dari pengunjung, ada yang mengatakan dengan adanya bazaar multi produk sangat membantu mereka untuk mendapatkan barang-barang yang mereka inginkan dengan harga terjangkau serta pilihannya lebih bervariasi. Akan tetapi ada yang juga berpandapat bahwa dengan adanya bazaar multi produk dan banyaknya produk di luar Kebudayaan Betawi yang ditawarkan menjadikan produk lokal asli Betawi tergeser keberadaanya, dikarenakan produk lokal lebih sedikit dibanding produk lain. Dengan begini, pengunjung yang datang ke Festival Palang Pintu yang seharusnya mereka ingin mengenal apa saja kesenian atau kerajinan tangan dari Betawi pada acara tersebut menjadi hanya sekedar mengetahui kesenian atau kerajinan tangan yang itu- itu saja. Padahal masih banyak hal yang berkaitan tentang Kebudayaan Betawi yang harus diperkenalkan.

\section{Seni Bangunan}

Hardjowigeno et al. (1994) mengatakan bahwa seni bangunan mencakup arsitektur rumah tinggal, rumah peribadatan dan monumen. Tetapi pada unsur ini hanya terlihat arsitektur rumah tinggal, karena tidak terdapat rumah peribadatan dan monumen yang menggambarkan seni Budaya Betawi. Serta melihat dari sejarah kawasan Kemang yang dulu terdapat banyak warga asli Betawi sehingga ada perkampungan Betawi di kawasan Kemang dan adapula bangunan rumah tinggal warga asli Betawi yaitu "Rumah Kebaya" yang kini bangunan tersebut sudah jarang ditemui di sekitar kawasan Kemang. Terdapat replika bangunan Rumah Kebaya di Padepokan Manggar Kelape, tetapi bangunan tersebut tidak seutuhnya berbentuk seperti rumah tinggal tetapi hanya memanfaatkan halaman depan sanggar dan ditambahkan arsitektur seperti gigi balang untuk pagar dan atapnya. Dari hasil observasi yang ada di lapangan, beberapa pengunjung tidak mengetahui bahwa di Kelurahan Bangka tepatnya di kawasan Kemang terdapat bangunan Rumah Kebaya meskipun hanya berupa replika dari bangunan Rumah Betawi. Letak Padepokan Manggar Kelape yang berada di Jl. Kemang Selatan X A/XII No. 2, Bangka, Mampang Prapatan, Jakarta Selatan berada di jalan buntu sehingga akses menuju tempat tersebut sulit untuk dilalui, membuat masyarakat dari luar kawasan Kemang tidak mengetahui bangunan tersebut. Selain itu banyak orang yang tidak tahu jika kawasan Kemang juga melatarbelakangi warga dan Kebudayaan Betawi, karena kondisi Kemang sekarang menjadi kawasan elite maka tidak banyak lahan untuk membangun kembali bangunanbangunan asli Betawi.

\section{Pagelaran Budaya}

Pagelaran budaya mencakup pertunjukan seni musik Budaya Betawi, terdapat seni musik yang ditampilkan di Festival Palang Pintu, antara lain musik Gambang Kromong, Tanjidor, macammacam Rebana dan lain-lain yang dimainkan oleh sanggar-sanggar Betawi yang ada di acara tersebut. Terdapat pula pertunjukan musik yang diperlombakan 
yaitu perlombaan Band yang dimainkan oleh pemuda/pemudi se-Jabodetabek. Menurut pendapat pengunjung yang didapat dari hasil observasi di lapangan, bahwa seni musik asal Betawi sangatlah mutlak menjadi pengisi acara di suatu acara Kebudayaan Betawi. Karena selain untuk menghidupkan atau memeriahkan suasana, dengan adanya seni musik tersebut secara tidak langsung menjadi suatu pengetahuan bagi anak-anak serta masyarakat dari daerah lain.

Pagelaran tari yang bertemakan budaya betawi di Festival Palang Pintu, terdapat beragam seni tari asal Betawi yang ditampilkan di Festival Palang Pintu, diantaranya Tari Lenggang Nyai, Tari Yapong, Tari Topeng, Tari Sirih Kuning, Tari Renggong Manis, Tari Tarub dan masih banyak lagi. Seni tari tersebut dilakukan oleh anak-anak binaan Padepokan Manggar Kelape dan komunitas-komunitas Betawi lainnya. Penampilan tari-tarian tersebut ditampilkan di panggung utama dan di mini stage. Dan tari-tarian tersebut dijadikan perlombaan bagi anak-anak muda yang ingin melestarikan kesenian Budaya Betawi. Selain penampilan dari tarian Betawi, terdapat pula tarian asal daearah lain seperti dari Aceh dan Padang. Dari hasil observasi yang didapat di lapangan, pengunjung sangat menikmati penampilan tari-tarian dari berbagai daerah. Karena dengan kebaragaman seni tari yang ditampilkan dapat menambah pengetahuan selain Budaya Betawi. Dengan adanya perlombaan tari tersebut, pengunjung berharap anak-anak muda saat ini atau yang akan datang dapat lebih melestarikan dan menjaga kebudayaan mereka masing-masing agar tidak termakan oleh zaman.

\section{Partisipasi Masyarakat dalam Penyelenggaraan Festival Palang Pintu}

Partisipasi dari masyarakat dalam Festival Palang Pintu dimulai dari usia muda hingga usia tua. Hal ini dikarenakan masyarakat tersebut ingin melestarikan dan memperkenalkan Budaya Betawi kepada masyarakat luas serta kepada generasi yang akan datang, sehingga Kebudayaan Betawi tidak akan hilang dengan adanya multikultural yang diakibatkan oleh adanya masyarakat pendatang yang menetap dan tinggal di kawasan Kemang. Kawasan Kemang sudah menjadi identik sebagai kawasan hiburan yang akan menimbulkan berbagai macam gaya hidup dan perilaku orangorang yang berkunjung ke kawasan Kemang. Secara tidak langsung hal tersebut akan berdampak pula terhadap kehidupan sosial masyarakat asli Kemang.

Dilihat dari sejarahnya bahwa Festival Palang Pintu itu diadakan oleh masyarakat setempat dibawah naungan komunitas Betawi seperti Forkabi (Forum Komunikasi Anak Betawi) DPRt Bangka Kemang dan Padepokan Manggar Kelape. Hal tersebut itu menjadikan masyarakat yang tinggal di kawasan Kemang dan di luar dari komunitas Betawi tertarik untuk ikut berpartisipasi dalam Festival Palang Pintu.

Berikut ini adalah analisis data yang dilakukan untuk mengetahui tingkat partisipasi masyarakat dalam Festival Palang Pintu yang meliputi Analisis Statistik Deskriptif, Transformasi Data Ordinal menjadi Data Interval, Skoring dan Deskriptif Kualitatif yang diolah menggunakan aplikasi Microsoft Excel.

\section{Analisis Data Deskriptif}

Menurut Muhson (2006) dalam Nurgahenny (2016) mengatakan analisis statistik deskriptif yaitu mengakumulasikan data secara deskriptif tanpa menguraikan hubungan, menguji hipotesis, bahkan melakukan penarikan kesimpulan. Dalam analisis data deskriptif yang digunakan pada penelitian ini berupa penyajian data dalam bentuk diagram sehingga diketahui kecenderungan hasil 
temuan penelitian yang masuk dalam kategori rendah, sedang atau tinggi.

2. Transformasi Data Ordinal menjadi Data Interval

Hasil data yang diperoleh dari kuesioner masih berupa data ordinal dan harus ditransformasikan menjadi data interval dari data per responden pada kuesioner yang sudah disebarkan, hal ini dilakukan untuk mencari presentase yang dimana hasil transformasi tersebut dapat dikategorikan ke dalam tingkatan partisipasi. Untuk mengolah data pada analisis data ini menggunakan aplikasi Microsoft Excel

\section{Analisis Skoring}

Setelah melakukan transformasi data ordinal menjadi data interval, kemudian mencari skoring untuk mengukur tingkatan partisipasi masyarakat pada Festival Palang Pintu. Skoring ini dilakukan dengan cara sebagai berikut:

$\mathrm{ST}=\left(\right.$ skor minimum $\left.+\frac{\mathrm{SK} \max -\mathrm{SK} \min }{2}\right) \pm \mathrm{SD}$

Keterangan:

ST :Selang tengah

SK min:Penjumlahan skor terendah dari semua item jawaban kuesioner

SK max:Penjumlahan skor tertinggi dari semua item jawaban kuesioner

SD :Standar deviasi/simpangan baku $=\sqrt{ } s 2$

Dari data yang telah diolah menggunakan aplikasi Microsoft Excel dengan cara yang disebutkan diatas maka hasil data skoring untuk pengukuran partisipasi masyarakat dalam Festival Palang Pintu dikelompokkan dalam tiga kategori skor, yaitu:

Rendah : 41,75

Sedang : 46,59

Tinggi : 61,59

4. Analisis Deskriptif Kualitatif
Dari hasil data yang sudah diolah maka dalam analisis deskriptif kualitatif ini menunjukkan bahwa tingkat partisipasi dalam Festival Palang Pintu berada pada partisipasi sedang yaitu ketika responden menyadari bahwa partisipasi masyarakat penting dalam suatu penyelenggaraan acara, namun tidak memahami bagaimana cara mengelola penyelenggaraan acara

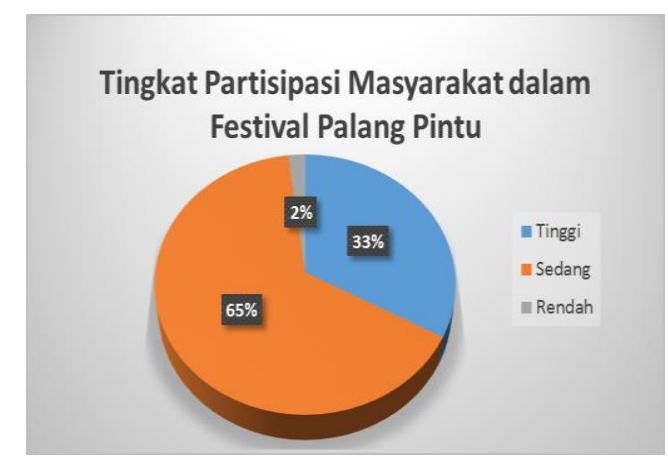

tersebut agar tersedia secara berkelanjutan.

Sesuai dengan teori Pretty (1995) yang mengemukakan ada 7 (tujuh) tipologi partisipasi yang menggambarkan kategori partisipasi dari yang paling rendah yang dinamakan Partisipasi Manipulasi hingga partisipasi yang menempati level tertinggi dengan terbentuknya Kemandirian. Menurut hasil analisa data yang dilakukan maka penelitian ini merupakan partisipasi Konsultasi yang berada pada tingkatan sedang sesuai dengan hasil yang didapat di lapangan. Pengertian Konsultasi menurut Pretty (1995) adalah dimana masyarakat berpartisipasi secara konsultatif sedangkan orang luar mendengarkan, menganalisa masalah dan pemecahannya. Belum ada peluang untuk pembuatan keputusan bersama. Para profesional tidak berkewajiban untuk mengajukan pandangan masyarakat (sebagai masukan) untuk ditindak lanjuti. Melihat kondisi partisipasi masyarakat kawasan Kemang dalam Festival Palang Pintu yang berada pada tingkat sedang dan merupakan partisipasi Konsultasi maka dapat diartikan bahwa masyarakat hanya akan ikut berpartisipasi jika pihak pengelola melakukan sosialisasi untuk mengajak 
atau mengikutsertakan masyarakat tersebut serta adanya imbalan yang berupa uang atas kegiatan di dalam Festival Palang Pintu.

Menurut gambar di atas menunjukkan bahwa tingkat partisipasi masyarakat dalam Festival Palang Pintu berada pada tingkat Sedang dengan 65 persen dan data tersebut diperoleh dari masyarakat yang tinggal di kawasan Kemang. Masyarakat tersebut di luar dari anggota komunitas Betawi yang menjadi pengelola dari acara tersebut. Hal ini dikarenakan masyarakat di kawasan Kemang didominasi oleh masyarakat pendatang, sehingga mereka hanya sekedar ikut berpartisipasi seperti halnya mereka hanya menjadi panitia operasional di acara tersebut dan mereka tidak berpartisipasi dalam tahap perancanaan hingga pada tahap evaluasi. Sesuai dengan pernyataan Ngakan (2006) dalam Nurgahenny (2016), partisipasi dikatakan sedang apabila responden menyadari sumber hayati hutan penting untuk menopang kehidupan, namun tidak memahami cara mengelola sumberdaya tersebut agar tersedia secara berkelanjutan. Dengan pengertian tersebut bahwa responden menyadari partisipasi masyarakat penting dalam suatu penyelenggaraan acara, namun tidak memahami bagaimana cara mengelola penyelenggaraan acara tersebut agar tersedia secara berkelanjutan.

Kemudian pada tingkatan yang tinggi dengan 33 persen, menunjukkan bahwa pada tingkatan ini merupakan partisipasi dari masyarakat asli Kemang atau masyarakat Betawi yang ada di Kemang. Mereka berpartisipasi mulai dari tahap perencanaan hingga evaluasi. Dalam hal ini masyarakat asli Kemang ingin mengikuti proses dari awal hingga akhir demi ikut serta melestarikan dan memperkenalkan Budaya Betawi di kawasan Kemang.

Dan pada tingkatan yang terendah dengan 2 persen, hal ini menunjukkan hanya sedikit dari masyarakat yang ikut berpartisipasi dalam Festival Palang Pintu, seperti masyarakat hanya sekedar mendukung dengan adanya acara tersebut, tetapi tidak ikut serta dalam proses baik operasional maupun perencanaan.

\section{Hubungan Partisipasi Masyarakat dengan Karakterisitik Masyarakat}

\begin{tabular}{|l|c|}
\hline \multicolumn{1}{|c|}{ Hubungan } & $\begin{array}{c}\text { Koefisien } \\
\text { Korelasi }\end{array}$ \\
\hline Umur dengan Partisipasi & $-0,48$ \\
\hline $\begin{array}{l}\text { Jenis Kelamin dengan } \\
\text { Partisipasi }\end{array}$ & 0,34 \\
\hline
\end{tabular}

Berdasarkan hasil uji statistik korelasi Spearman menunjukkan pada hubungan partisipasi dengan umur nilai koefisien korelasi sebesar -0,48 yang menunjukkan bahwa ada korelasi yang negatif dan sangat lemah, sehingga bisa dikatakan tidak ada hubungan. Nilai sig. 0.717, berarti lebih besar dari 0,05 jadi tidak terdapat korelasi yang signifikan antara jenis usia dengan partisipasi masyarakat. Hal tersebut disebabkan karena partisipasi dalam Festival Palang Pintu dari masyarakat tidak dilihat dari jenis usia, dari muda hingga usia tua. Sesuai dengan pengamatan langsung di lapangan bahwa masyarakat yang ikut berpartisipasi tidak mengenal usia, jadi dari usia muda hingga usia tua ikut serta melestarikan dan memperkenalkan Festival Palang Pintu itu sendiri.

Dan berdasarkan hasil uji korelasi Spearman antara jenis kelamin dengan partisipasi masyarakat nilai koefisien korelasi sebesar 0,34 yang menunjukkan bahwa korelasi positif tapi sangat lemah, sehingga bisa dikatakan tidak ada hubungan. Hal ini berarti semakin meningkat partisipasi, maka jenis kelamin semakin meningkat. Nilai sig. 0.799, 
berarti lebih besar dari 0,05 jadi tidak terdapat korelasi yang signifikan antara jenis kelamin dengan partisipasi masyarakat. Sama halnya dengan hubungan jenis usia dengan partisipasi, partisipasi dalam Festival Palang Pintu dari masyarakat tidak dilihat dari jenis kelaminnya. Dilihat dari hasil observasi bahwa masyarakat yang ikut berpartisipasi dalam Festival Palang Pintu tidak melihat dari golongan tertentu, baik perempuan dan laki-laki semua turut andil dalam bagian melestarikan dan memperkenalkan Festival Palang Pintu ke masyarakat luas.

\section{KESIMPULAN}

Berdasarkan hasil penelitian dengan judul Partisipasi Masyarakat dalam Festival Palang Pintu sebagai atraksi Wisata Budaya di Kawasan Kemang, dapat disimpulkan bahwa Festival Palang Pintu terdapat beberapa unsur budaya yaitu seni budaya berupa kerajinan tangan, tata cara adat, pesta rakyat serta produk lokal yang masing-masing mencerminkan Budaya Betawi. Pada unsur seni bangunan, tidak terdapat arsitektur rumah tinggal asli Budaya Betawi yaitu "Rumah Kebaya", karena kawasan Kemang yang menjadi kawasan elite dengan bangunan yang didominasi dengan rumah mewah, kafe, serta tempat hiburan dan lain-lain membuat tidak tersedianya lahan yang cukup untuk didirikan bangunan rumah tinggal asli Betawi itu sendiri. Tetapi komunitas Betawi seperti Padepokan Manggar Kelape mempunyai rasa simpati terhadap seni-seni budaya Betawi sehingga mereka membangun replika "Rumah Kebaya" meskipun tidak berbentuk bangunan secara utuh. Dan dalam pagelaran budaya di Festival Palang Pintu terdapat seni musik dan seni tari yang didominasi dengan kebudayaan Betawi serta daerah lain. Hal ini menunjukkan bahwa tidak hanya Kebudayaan Betawi saja yang ditampilkan di Festival Palang Pintu, tetapi banyak dari daerah lain yang ikut berpartisipasi dalam acara tersebut. Dengan begitu masyarakat atau pengunjung dapat mengetahui kebudayaan-kebudayaan dari daerah lain.

Dan Festival Palang Pintu yang diselenggarakan di kawasan Kemang dapat menjadi potensi sebagai atraksi wisata budaya di Jakarta dengan melihat dari teori Hardjowigeno et al. (1994), tetapi lebih diperhatikan dalam hal unsur seni bangunannya karena hal ini juga untuk menunjang Festival Palang Pintu dijadikan sebagai atraksi wisata budaya.

Dalam partisipasi masyarakat di Festival Palang Pintu dikategorikan sedang yang merupakan partisipasi Konsultasi, dimana dapat diartikan masyarakat hanya ingin berpartisipasi apabila terdapat ajakan atau permohonan untuk ikut serta dengan adanya imbalan dari kegiatan Festival Palang Pintu. Hal ini dikarenakan masyarakat yang berada di kawasan Kemang mayoritas adalah pendatang bukan masyarakat asli dari Kemang itu sendiri. Jadi mereka tidak sepenuhnya berpartisipasi untuk melestarikan serta memperkenalkan Kebudayaan Betawi pada masyarakat luas.

Dan dalam hubungan antara partisipasi dengan karakteristik masyarakat dapat disimpulkan bahwa dalam Festival Palang Pintu tidak dilihat dari hubungan partisipasi ke jenis usia dan jenis kelamin, dikarenakan Festival Palang Pintu merupakan wadah untuk semua jenis golongan yang ingin ikut serta berperan penting dalam melestarikan serta memperkenalkan Budaya Betawi sehingga acara tersebut dari tahun 2006 sudah berjalan setiap tahun hingga 12 kali sampai saat ini.

\section{DAFTAR PUSTAKA}

Jurnal

Pretty \& Jules N. 1995. Participatory Learning For Sustainable Agriculture. International Institute for Environment and 
Development. J Sustainable Tour. 23(8):1247-1263. doi:0305$750 X / 95 \$ 9.50$ ancasila

$\underline{B u k u}$

Creswell, JW. 2010. Research Design Pendekatan Kualitatif, Kuantitatif, dan Mixed. Yogyakarta: Pustaka Pelajar

Sugiyono, 2012. Metode Penelitian Bisnis. Bandung: Alfabeta

Disertasi/Tesis

Anita. 2016. Analisis Pengembangan dan Pengelolaan Kawasan Konservasi Penyu Sebagai Kawasan Ekowisata di Kota Pariaman. [Tesis]. Padang: Universitas Andalas

Internet

Duta Papua ikut serta dalam Karnaval Festival Palang Pintu. [Internet]. Tersedia pada: www.merdeka.com, (diakses pada 20 Juli 2017)

Sejarah kawasan Kemang dan Sejarah Festival Palang Pintu. [Internet]. Tersedia pada: www.jakarta.go.id, diakses 20 Juli 2017

Skripsi

Adi, IR. 2007. Perencanaan Partisipatoris Berbasis Aset Komunitas: dari Pemikiran Menuju Penerapan. Depok: FISIP UI Press

Kodariyah, R. 2005. Perencanaan Lanskap Kawasan Wisata Budaya Berbasis Indutri Kerajinan Gerabah di Desa Banyumulek, Kecamatan Kediri, Lombok Barat. [Skripsi]. Bogor: Institut Pertanian Bogor

Lestari, RA. 2014. Pengaruh Kepemimpinan Partisipatif dan Komitmen Organisasi Terhadap Efektifitas Implementasi Rencana Stratejik Pada Madrasah Aliyah di Kabupaten Sukabumi Jawa Barat.
[Skripsi]. Bandung: Universitas Pendidikan Indonesia

Ngakan. 2006. Ketergantungan, Persepsi dan Partisipasi Masyarakat terhadap Sumberdaya Hayati Hutan Studi Kasus di Dusun Pampli Kabupaten Luwu Utara, Sulawesi Selatan. Bogor: Center for International Forestry Research

Nurgahenny, CD. 2016. Persepsi Masyarakat Terhadap Pengelolaan Taman Wisata Alam Telogo Warno Telogo Pengilon. [Skripsi]. Bogor: Fakultas Kehutanan Institut Pertanian Bogor

Sastrayuda, GS. 2010. Konsep Pemberdayaan Masyarakat Berbasis Pariwisata (Hand Out Mata Kuliah Concept and Leisure, Strategi Pengembangan dan Pengelolaan Resort and Leisure)

Prasetyo, R. 2015. Kajian Potensi Kampung Cina Cibubur Sebagai Atraksi Wisata Budaya Di Kabupaten Bogor. [Skripsi]. Jakarta: Fakultas Pariwisata Universitas Pancasila 